Otterbein University

Digital Commons @ Otterbein

Psychology Faculty Scholarship

Psychology

$12-2018$

\title{
Gender Essentialism and Responses to Candidates' Messages
}

Meredith Meyer

Otterbein University, mmeyer@otterbein.edu

Follow this and additional works at: https://digitalcommons.otterbein.edu/psych_fac

Part of the Psychology Commons

\section{Repository Citation}

Meyer, Meredith, "Gender Essentialism and Responses to Candidates' Messages" (2018). Psychology Faculty Scholarship. 2.

https://digitalcommons.otterbein.edu/psych_fac/2

This Article is brought to you for free and open access by the Psychology at Digital Commons @ Otterbein. It has been accepted for inclusion in Psychology Faculty Scholarship by an authorized administrator of Digital Commons @ Otterbein. For more information, please contact digitalcommons07@otterbein.edu. 


\title{
Gender Essentialism and Responses to Candidates' Messages
}

\author{
Nathaniel Swigger \\ Department of Political Science, The Ohio State University \\ Meredith Meyer \\ Department of Psychology, Otterbein University
}

\begin{abstract}
People often form negative attitudes against those who deviate from gender norms. Within the political realm, this has the potential to translate into effects on perceptions of candidate likability and traits. Female candidates who tend to focus on issues stereotypically thought of as feminine are generally more positively evaluated than those who focus on stereotypically masculine domains. The current studies investigate whether these effects vary depending on the extent to which people endorse gender essentialism, which is the tendency to attribute gender differences to relatively more intrinsic, innate, and immutable factors versus believing that gender differences are largely due to cultural and learned factors. Current data with adults across two studies suggest a number of interesting findings: Evaluations of candidates depended on an interaction between respondents' gender essentialism and whether or not the candidate's message fit traditional stereotypes. In particular, high essentialist respondents felt significantly more negative toward male candidates with nonstereotypic messages.
\end{abstract}

KEY WORDS: campaigns, gender, gender essentialism, stereotypes

More and more women have begun to seek elected office in the United States, and as the number of female candidates has increased, there has been a commensurate increase in interest in campaign strategy for female candidates. Most of the research in this area has focused on how gender stereotypes affect views of female candidates and how candidates should moderate their messages to take account for those stereotypes. Findings consistently show that women are better off running on "women's issues" like health care and childcare (Herrnson, Lay, \& Stokes, 2003; Meeks \& Domke, 2016).

While there is a general consensus that gender stereotypes shape people's views of candidates, it is less clear how individual predispositions interact with gender-stereotypic campaign messages, how the effect of these predispositions might change depending on the gender of the candidate, and why those stereotypes might matter. In the current study, we investigated whether gender essentialism-that is, the tendency to construe gender as largely or exclusively biological, discrete, binary, and innate-relates to people's evaluations of candidates who either conform to or violate gender stereotypes.

We present two separate experiments, both of which address whether people's essentialism predicts their evaluations of male and female stereotype-conforming vs. stereotype-violating candidates. In our first study, we presented an adult online sample with fictional news stories about 
prospective U.S. Senate candidates in order to examine responses to male and female candidates who ran on platforms that were either stereotypically masculine (infrastructure and national defense) or feminine (childcare and education). We find that respondents' feelings about the candidates and reactions to these messages differ according to the strength of their gender essentialist beliefs, particularly for male candidates. In our second experiment, we expand on these findings and use video campaign ads to demonstrate how these effects might work in a real campaign. Even with less control in the second experiment, the results largely mirror those of the more tightly controlled first experiment. In the following sections, we review research on gender essentialism and gender effects in candidate evaluation, and we discuss how these beliefs may be relevant for judgments of political candidates.

\section{Gender Essentialism}

Of course, voters may vary tremendously in how much they accept gender stereotypes, and that variance could alter how they respond to stereotypic and nonstereotypic campaigns. The current study assesses another potentially important mitigating factor in candidate evaluations: gender essentialism. Gender essentialism is seen within psychology as one manifestation of a broader set of beliefs known as psychological essentialism. Two main beliefs are consistent with psychological essentialism. First, essentialized categories are seen as natural kinds, with many deep and nonobvious commonalities. Second, these commonalities are attributed to an "essence," one which is innate, stable, and immutable (Gelman, 2003; Medin \& Ortony, 1989). People often essentialize a range of categories, including biological species (e.g., tiger, dog) but also, relevant to the current study, social groups (e.g., woman).

Rothbart and Taylor (1992) introduced an initial analysis of essentialism in the context of social categorization, noting that social categories are often treated as if they are natural kinds (e.g., they are often assumed to be united by a deep and natural underlying basis and immutably similar to each other), despite their often having more similarities to human-made artifact categories (influenced by the social environment, constructed by people, culturally variable). More recent empirical investigations confirmed Rothbart and Taylor's theoretical position. People often essentialize human characteristics and abilities, including assuming that elements of intellectual abilities and personality are fixed (i.e., endorsing entity theories, in contrast with incremental theories) (e.g., Chiu, Hong, \& Dweck, 1997; Dweck, 1999; Haslam, Bastian, Bain, \& Kashima, 2006). Moreover, many social categories, including gender, race, ethnicity, sexual orientation, and caste are often essentialized to some degree as well, including endorsement of entity views of category membership as well as attributing categories to largely natural, innate, and biological origins (Gil-White, 2001; Haslam, 2000; Haslam \& Ernst, 2002; Haslam, Rothschild, \& Ernst, 2002; Hirschfeld, 1996; Mahalingam, 2007; Prentice \& Miller, 2007; Rhodes \& Gelman, 2009). ${ }^{1}$

Essentialist thinking begins at an early age (for a thorough review, see Gelman, 2003), and in particular, children begin to make at least some essentialist assumptions about gender as early as the preschool and early elementary years, long before most people begin to develop political views (e.g., Biernat, 1991; Diesendruck \& Haber, 2009; Gelman, Collman, \& Maccoby, 1986; Rhodes \& Gelman, 2009; Taylor, Rhodes, \& Gelman, 2009). The fact that essentialism develops in advance of political awareness and partisanship is important; though awareness and partisanship have clear and extensively researched roles in directing people's political views, one's earlier-developed

\footnotetext{
${ }^{1}$ We note that the current research on gender essentialism, and indeed all research on psychological essentialism in general, does not argue for the actual validity of essentialism. In the context of this study, our investigation is thus not directed toward uncovering or arguing for some "true" nature of gender and stakes no claim in the ongoing empirical and theoretical debates regarding the extent to which gender is biologically informed and innate versus environmentally and socially constructed. Rather, the focus is on investigating the kinds of behaviors that are associated with essentialist beliefs, which vary in strength across individuals.
} 
essentialism is a separate and perhaps equally important influence on one's worldview, motivating our current focus.

The tendency to essentialize social groups can have implications for social cognition more broadly, including stereotyping. At least two distinct forms of stereotyping have been addressed by past research. First, essentialism can encourage descriptive stereotyping, or drawing generalizations about what social groups are like. This arises because essentialized categories are assumed to be highly similar by virtue of possessing the same essence, and once a specific feature or behavior is observed in one person, it may often be assumed to characterize the entire category to which that person belongs (Bastian \& Haslam, 2006; Levy, Stroessner, \& Dweck, 1998; Prentice \& Miller, 2006; Yzerbyt, Corneille, \& Estrada, 2001). Second, essentialism can promote prescriptive stereotyping, or beliefs about what social groups should be like. This form of stereotype strengthening comes about because essentialism also involves the creation of an explanatory structure whereby differences between categories are assumed to be natural. In the case of thinking about social groups, this assumption can then prompt legitimating ideologies that justify social-group differences as inevitable, acceptable, and correct (Eagly, Wood, \& Diekman, 2000; Hoffman \& Hurst, 1990; Yzerbyt, Rocher, \& Schadron, 1997; Yzerbyt, Rogier, \& Fiske, 1998).

Within research on gender specifically, findings confirm that both descriptive and prescriptive stereotypes can be promoted by essentialist thinking. For example, endorsement of biological versus social causes of gender differences predicts greater perceived differences between men and women (Martin \& Parker, 1995). In some experiments, introducing a biological explanation for gender differences promotes how strongly people endorse common descriptive gender stereotypeseven when the difference being described (i.e., skill in plant identification) was unrelated to the stereotypical qualities presented to the participants (e.g., being emotional) (Brescoll \& LaFrance, 2004). Gender essentialism has also been found to predict the strength of certain forms of sexism (Smiler \& Gelman, 2008) as well as endorsement of prescriptive gender stereotypes regarding men's and women's occupations and activities (Meyer \& Gelman, 2016), which is particularly relevant in the political world given the way political leadership has often been viewed through a gendered lens (Dolan, Deckman, \& Swers, 2015). Finally, being exposed to the idea that gender differences have a genetic basis - an idea consistent with essentialism - can promote beliefs in the legitimacy and inevitability of male-female power inequality (Morton, Postmes, Haslam, \& Hornsey, 2009).

\section{Essentialism, Gender Stereotypes, and Campaign Appeals}

The connection between gender essentialism and gender stereotypes is particularly important for this study. Studies of gender stereotypes have shown that men are typically viewed more favorably on traits like competence, strength, and decisiveness (Burrell, 2008; Huddy \& Terkildsen, 1993; Paul \& Smith, 2008). Literature on management and business has revealed that people tend to "think leader, think male" (Schein, Mueller, Lituchy, \& Liu, 1996). When people think of traits related to leadership, they often think of traits that they stereotypically associate with men. Therefore, there is a tendency to link leadership and masculinity. Though some of the traits that we associate with leadership have shifted over time, this tendency to associate men and leadership has persisted (Offermann \& Coates, 2017).

Similarly, the literature on women in politics has often focused on the ways that gender stereotypes limit women's opportunities. Women are often less inclined to see themselves as qualified for political office (Fox \& Lawless, 2005, 2010 ), and politics is often seen as a male dominated game. Gender stereotypes can similarly create an automatic preference for male political leadership (Sanbonmatsu, 2002) and put women at an automatic electoral disadvantage (Dolan et al., 2015; Lawless, 2004). In addition, Americans don't necessarily accept women for all kinds of positions or under all circumstances. While women do well in legislative elections, they often fare worse when 
running for executive positions as voters struggle to accept a woman in a stereotypically male-leadership role (Smith, Paul, \& Paul, 2007; Streb, Burrell, Frederick, \& Genovese, 2008). Similarly, women may be less successful when issues like terrorism or national security are more important to voters because men are perceived as better suited to handle these issues (Holman, Merolla, \& Zechmeister, 2011).

The prevalence of gender stereotypes also influences campaign strategies. In addition to individual traits, voters often associate women with liberal ideology (Koch, 2002; McDermott, 1997) and also view women as having more expertise on more stereotypically feminine issues, such as health care, childcare, and education (Dolan, 2010; Fridkin \& Kenney, 2009; Sanbonmatsu \& Dolan, 2009). Campaign research since Downs (1957) has argued that candidates are better off when they highlight issues where the public is already on their side, rather than trying to persuade voters to change positions. Candidates, for a variety of reasons, do not always center their campaigns around issues they own or that coincide with popular opinion, and these candidates often underperform in elections (Kahn \& Kenney, 1999; Simon, 2002). Because issues like childcare and health care are owned by women, female candidates can take advantage by making these issues the focus of their campaigns. Most campaign research suggests that women are better off running "as women" (Herrnson et al., 2003; Meeks \& Domke, 2016), and political consultants often encourage female candidates to embrace this stereotype (Dittmar, 2015). Women who try to run counterstereotypic campaigns may only deemphasize the importance of women's issues without actually gaining any advantages with voters because they are not seen as experts beyond these issues (Schneider, 2014).

Research on gender and campaigns has curiously little to say about how stereotypes might affect male candidates. Most likely, this absence is due to the ubiquity of male candidates throughout American history. But if women are better off running "as women," are men better off running "as men" by emphasizing issues like national defense or criminal justice? There is some indication that gender stereotypes may not matter as much for male candidates. Indeed, Fridkin and Kenney (2009) found little evidence that men actually owned any issues at all or were seen as better than women on traditionally masculine issues. Schneider (2014) actually found that men (more so than women) can benefit from running counterstereotypic campaign appeals, and Cassese and Holman (2018) found that negative ads attacking opponents with gender counterstereotypic language hurt female candidates substantially more than male candidates.

Of course, how campaign messages affect voters may depend on the voters' views prior to the campaign. As Dolan (2014b) points out, stereotype strength varies strongly across individuals and suggests the possibility that "the impact of stereotypes [could be] neutralized as the actions of those who hold stereotypes are balanced out by those who hold more egalitarian views" (p. 24). Indeed, Schneider and Bos (2014) found variance in how tightly individuals clung to gender stereotypes and how they applied those stereotypes to male and female (and Democratic and Republican) politicians. If stereotype strength matters and obviously varies across individuals, essentialism may very well be one of the important predictors of that individual difference and could help predict when and where stereotypic and counterstereotypic campaign appeals may be most effective.

We predict that higher levels of essentialism, by virtue of its relationship with prescriptive stereotyping, will promote more positive evaluations of candidates who conform to gender norms. Adults who have higher levels of gender essentialism are predicted to prefer female candidates who talk about feminine issues and male candidates who talk about masculine issues. Conversely, they are also predicted to punish candidates who transgress and violate stereotypes.

On the other side of the spectrum, we expect adults low in gender essentialism to be more open to candidates who run counterstereotypic messages. They may respond more positively to counterstereotypic gender appeals, but at the very least, we would expect them not to punish candidates who use such appeals. This is particularly important since a decline in belief in stereotypes in the public could be associated with increased opportunity and flexibility for political candidates. If, as we 
expect, adults low in essentialism respond favorably, or even just neutrally, to women who talk about national defense and men who talk about childcare, that could indicate that a wide swath of voters respond favorably to candidates who shed traditional stereotypes.

\section{STUDY 1}

\section{Method}

In our first experiment we examined how gender essentialism related to responses to a fictional candidate described in a news article. Following a method similar to Meeks and Domke (2016), we used a $2 \times 2$ design varying the gender of the candidate and whether or not that candidate focused on stereotypically masculine or feminine issues. This format allowed us a high degree of control, ensuring that the only things that varied between conditions were the gender of the candidate and the nature of the candidate's message. (Note that to increase realism of the article, we did identify the partisanship of the candidate, but we held this constant across all conditions; namely, the candidate was described as a Democrat.) We recruited respondents through Amazon Mechanical Turk and offered respondents $\$ 1$ in exchange for completing a short study. Table 1 shows the demographic breakdown within both our studies. Mechanical Turk offers a convenience sample rather than a fully nationally representative sample. Analyses of American MTurk workers have demonstrated that women are overrepresented, that workers are typically younger than average, and that ethnic and racial minorities are underrepresented (Berinsky, Huber, \& Linz, 2012; Paolacci \& Chandler, 2014). These differences are replicated in our sample (see demographics in Table 1). Thus, we do not claim to be capturing beliefs that are fully representative of the U.S. public. Fifteen responses that came from IP addresses outside of the United States were removed from the dataset.

The final sample for Study 1 consisted of 366 respondents, who were randomly assigned to one of our four conditions (male stereotype-conforming, female stereotype-conforming, male stereotype-violating, female stereotype-violating). In each condition, respondents read a news article about a candidate (Brian/Laura Taylor) announcing his/her Senate campaign. In half the conditions, the candidate was quoted on masculine issues, namely national defense and supported increased infrastructure spending. In the other half, the candidate focused on feminine issues, namely support for education and affordable childcare. ${ }^{2}$ (The stereotype-conforming conditions featured male candidates discussing masculine issues and female candidates discussing feminine issues, and the stereotype-violating conditions featured the reverse). The articles presented in the experiment can be found in Appendix S1 in the online supporting information. After reading the article, respondents were asked to rate the candidate on a feeling thermometer (responses ranged 0-100, with favorable impressions indicated by higher numbers), as well as rate the candidate on the traits of warmth, competence, and authenticity (responses ranged 1 to 5, with higher numbers indicating stronger levels of the trait of interest). Text of these items can be found in Appendix S2 in the online supporting information.

In addition, we asked respondents eight questions assessing gender essentialism (from Rhodes \& Gelman, 2009, Appendix II). Responses were averaged to reflect a single score, ranging 1 to 7 , with high scores indicating stronger gender essentialist beliefs. Finally, we asked respondents about their partisan identification, ideological self-placement, race, and gender.

\footnotetext{
${ }^{2}$ We did not run any pilot tests on the campaign messages used in these experiments. We chose instead to shape our candidates' messages around issues that previous research indicates voters see as stereotypically masculine or feminine issues (Dolan, 2010; Fridkin \& Kenney, 2009; Sanbonmatsu \& Dolan, 2009).
} 
Table 1. Descriptive Statistics for Participants

\begin{tabular}{|c|c|c|}
\hline & Study 1 & Study 2 \\
\hline \multicolumn{3}{|l|}{ Party } \\
\hline Democrat & 45.5 & 41.5 \\
\hline Republican & 16.5 & 19.6 \\
\hline Independent & 38.4 & 38.9 \\
\hline \multicolumn{3}{|l|}{ Ideology } \\
\hline Liberal & 54.5 & 48.9 \\
\hline Conservative & 17.9 & 25.2 \\
\hline Moderate & 27.1 & 25.5 \\
\hline Don't know & 0.2 & 0.2 \\
\hline \multicolumn{3}{|l|}{ Gender } \\
\hline Female & 43.7 & 35.1 \\
\hline Male & 56.3 & 64.9 \\
\hline \multicolumn{3}{|l|}{ Race } \\
\hline White & 74.5 & 79.8 \\
\hline African-American & 8.4 & 6.8 \\
\hline Latino & 6.5 & 3.8 \\
\hline Asian & 11.1 & 10.1 \\
\hline Native American & 0.5 & 0.5 \\
\hline Pacific islander & 0.5 & 0.3 \\
\hline Other & 0.5 & 1.5 \\
\hline \multicolumn{3}{|l|}{ Age } \\
\hline Range & $20-77$ & $20-76$ \\
\hline Median & 36 & 35 \\
\hline Mean & 39.5 & 37.7 \\
\hline$N$ & 369 & 337 \\
\hline
\end{tabular}

Note. Cell entries show the percentage of participants in each study who self-identified with each category.

\section{Results}

Table 2 shows the distribution of our trait variables broken down by condition. Our main interest, however, is the relationship between respondents' essentialism and how they react to stereotype-conforming versus stereotype-violating campaign issues. In order to test this, we estimated a series of ordered logit models using our traits as the dependent variables. We separated out male and female candidate conditions. We used a binary variable $(1=$ stereotype conforming, $0=$ stereotype violating) for the message conditions and created an interaction term between gender essentialism and candidate messages. We also included control variables for the respondent's partisan identity (1 $=$ Strong Democrat to $5=$ Strong Republican), respondent's age, and whether or not the respondent identified as female. (In earlier models, we also included respondent's political ideology. This did not alter our substantive findings, but it did create issues within the model due to the collinearity of ideology and political partisanship; thus it was dropped from the reported main analysis.)

The results of our ordered logit analysis can be found in Table 3 and show an unexpected difference in reactions to male and female candidates. For female candidates, a stereotypic message 


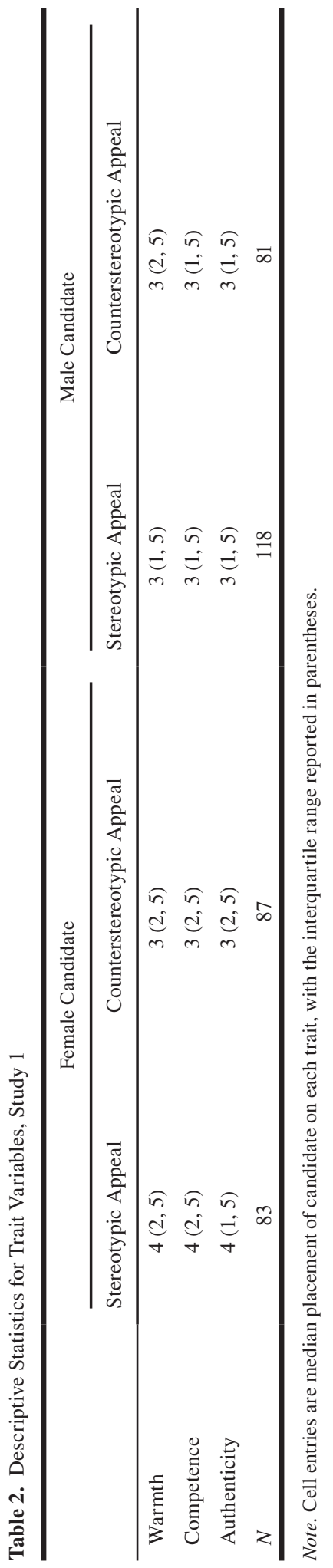




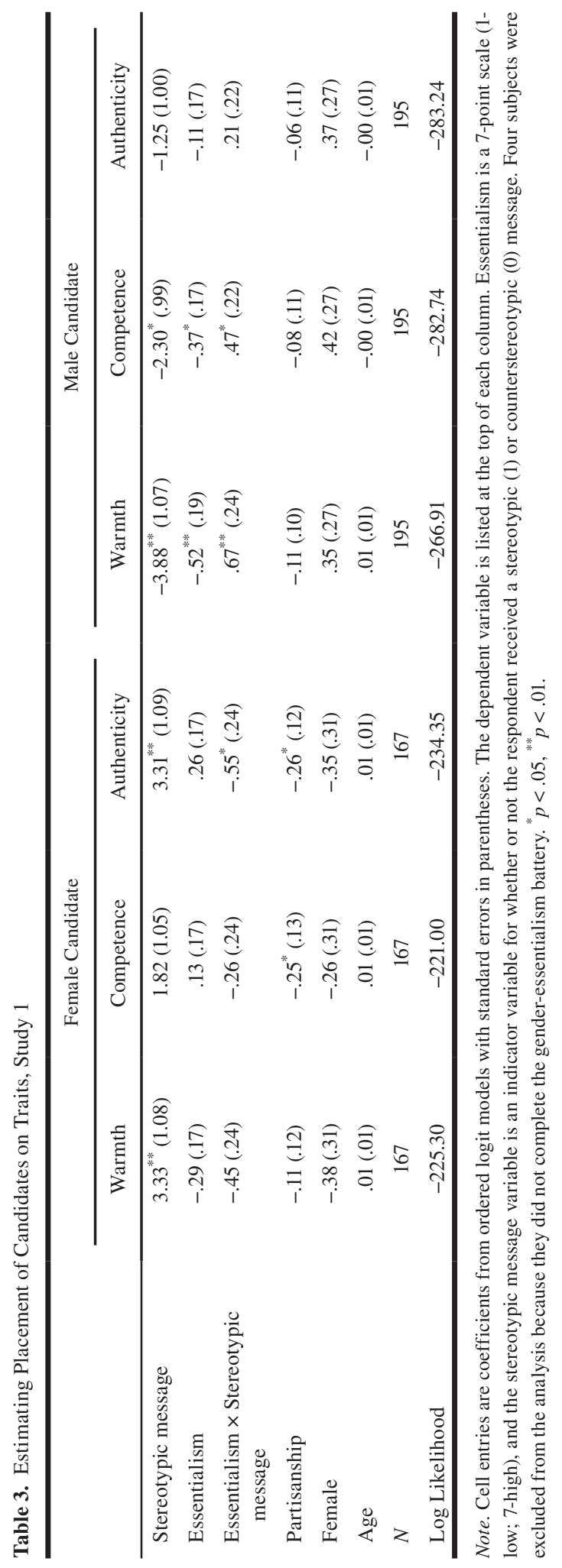


was much more successful than a nonstereotypic message, regardless of the respondents' gender-essentialist beliefs; the stereotypic message variable is positive and statistically significant for two of the three trait variables (warmth and authenticity), and the interaction variable is never statistically significant. This finding indicates that gender essentialism did not modify responses when the candidate is female, and it supports the notion that women are better off running "as women."

For male candidates, there is a more interesting trade-off. Once we controlled for participant gender and partisanship, we found a strong interaction between gender essentialism and candidate messages. For two of the three trait models, the message variable is statistically significant (warmth and competence), and the interaction between the message and the respondent's gender essentialism is also significant. This is because the stereotypic message had a positive effect on those high in essentialism and a negative effect on those low in essentialism. The reverse was true for the stereotype-violating message. In other words, high essentialist respondents were more impressed with a male candidate who has a stereotypically masculine message, but low essentialist respondents actually rated the male candidate higher when he used stereotypically feminine issues.

Turning to the feeling thermometer, we find largely similar results. Similar to our trait analysis, we focused on whether gender essentialism matters in respondents' feeling-thermometer ratings. We estimated a regression model including gender essentialism and controlling for respondent gender, age, and partisan affiliation, this time with the feeling thermometer as the dependent variable. Table 4 shows the results of this model. Unsurprisingly, partisanship has a significant impact on feeling-thermometer ratings, with participants identifying as Democrats providing more favorable evaluations of the candidate (who, recall, had been identified as a Democrat in all conditions). Respondent gender does not have a significant effect on feeling-thermometer ratings. Most importantly, even controlling for partisanship there is a significant effect from our message treatments. The interaction between gender essentialism and messaging, though, is only significant when the candidate is male; as with our findings on traits, low essentialists' feelings are more positive for the stereotype-violating male candidate, whereas high essentialists evaluate the stereotype-conforming male candidate more favorably. In contrast, stereotype-conforming message had a uniformly positive effect on respondent feelings toward the female candidate, regardless of the respondent's beliefs about gender essentialism.

Table 4. Estimating Feeling-Thermometer Ratings, Study 1

\begin{tabular}{lcc}
\hline & Female Candidate & Male Candidate \\
\hline Stereotypic message & $26.05^{*}(10.05)$ & $-27.18^{*}(12.25)$ \\
Essentialism & $2.98(1.64)$ & $-4.87^{*}(2.19)$ \\
Essentialism $\times$ Stereotypic message & $-2.71(2.32)$ & $6.05^{*}(2.76)$ \\
Partisanship & $-5.13^{* *}(1.38)$ & $-1.94(1.60)$ \\
Female & $3.66(2.92)$ & $5.11(3.25)$ \\
Age & $-.05(.12)$ & $-.11(.11)$ \\
Constant & $58.08(8.18)$ & $89.68(9.96)$ \\
$\mathrm{R}^{2}$ & .22 & .06 \\
$N$ & 167 & 194 \\
\hline
\end{tabular}

Note. Cell entries are coefficients from OLS model with standard errors in parentheses. The dependent variable is the respondent's placement of the candidate on a 0-100 feeling thermometer. Essentialism is a 7-point scale (1-low; 7-high), and the stereotypic message variable is an indicator variable for whether or not the respondent received a stereotypic (1) or counterstereotypic (0) message. Five subjects were excluded from the analysis either because they did not complete the gender-essentialism battery, or they did not rate the candidate. ${ }^{*} p<.05,{ }^{* *} p<.01$. 
Following a practice laid out by Kam and Franzese (2006), we took a derivative of our estimated regression equation with respect to the message variable. The derivative shows us the effect of the stereotypic message conditional on the respondent's level of gender essentialism. We then graphed the effect of stereotypic messages for male and female candidates as gender essentialism increases and show the results in Figure 1. Contrary to our expectations, for a female candidate, the effect of a stereotypic message is always positive. In fact, the impact of stereotypic messaging declines as gender essentialism increases (though the effect is still positive.) The largest positive effect of stereotypic messaging actually comes among respondents with the lowest level of gender essentialist beliefs. Again, it is the effect of stereotypic messaging with a male candidate where we actually see more complex results. When the candidate is male, stereotypic messages have a negative effect on feeling-thermometer ratings among low essentialist respondents. This effect decreases and actually becomes positive as gender essentialism increases.
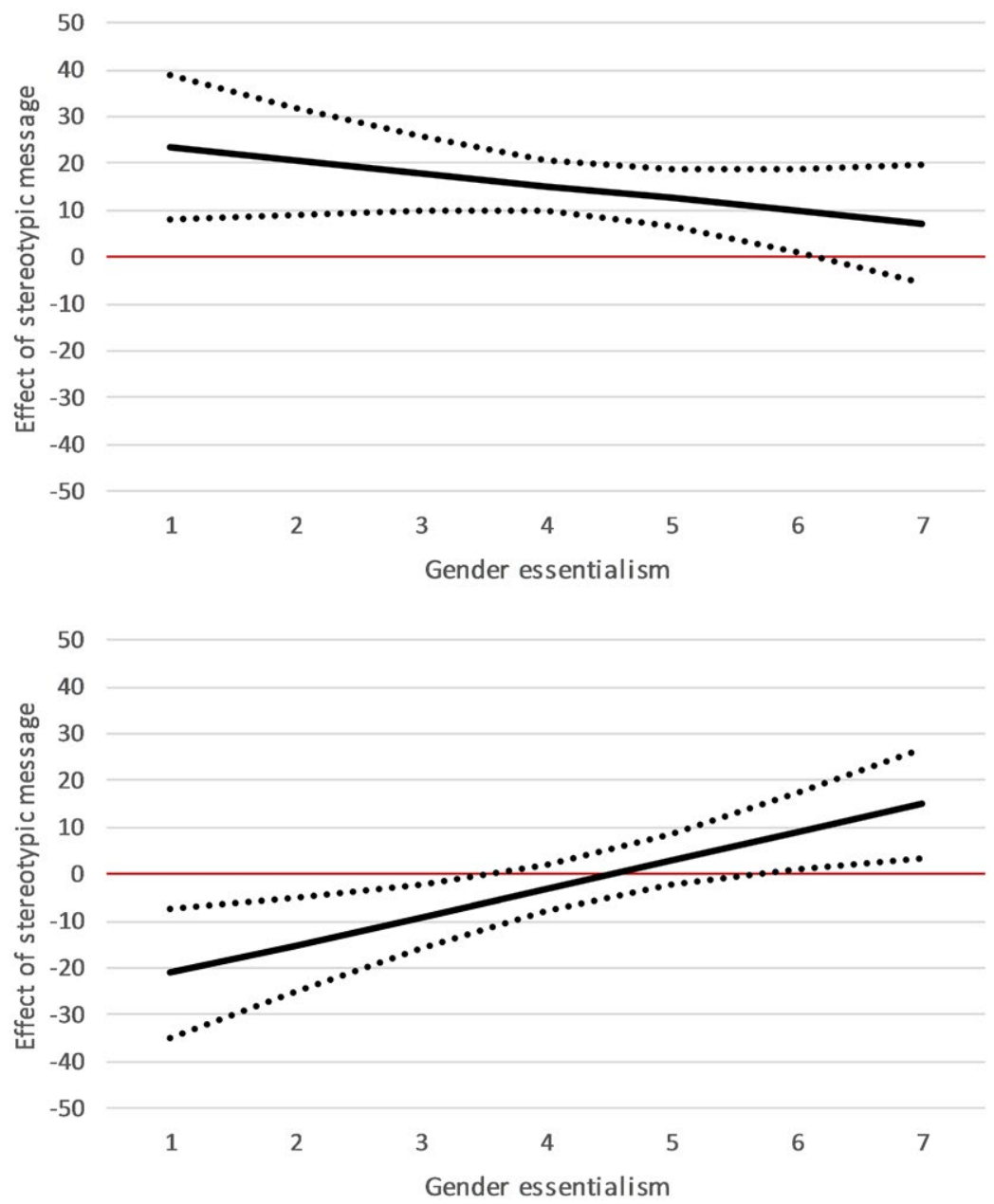

Figure 1. Conditional effect of stereotypic message, Study 1. Each figure shows the effect of a gender-stereotypic campaign message conditional on the respondent's level of gender essentialism. The figure shows the effect as well as the $95 \%$ confidence interval of the estimated effect. 
Overall, the results from our first experiment show differing effects from stereotypic messaging for male and female candidates. The results suggest that men may have more flexibility with the messages they choose. Female candidates may only and always be better off focusing on stereotypically feminine issues, but men may be able to benefit by pivoting between stereotypic and nonstereotypic appeals depending on what kind of audience they need to appeal to (i.e., if they have expectations that their audience is high on essentialism, they may benefit by focusing on stereotypically male issues, but if their audience is low on essentialism, they may be better off focusing on stereotypically female issues). In some ways, this may actually create an advantage for female candidates, since they always have an opportunity to benefit from stereotypic messages, whereas male candidates may have to worry about a backlash from some respondents. On the other hand, external factors often influence campaign messaging as candidates feel that they have to address salient issues or issues receiving media coverage (Kahn \& Kenney, 1999; Simon, 2002). Female candidates who feel forced to address masculine issues may find themselves in an impossible situation.

\section{STUDY 2}

\section{Method}

In our second experiment we shifted our treatment focus in an attempt to gain a more realistic response to campaign messaging. As in our first experiment, we recruited respondents $(n=334)$ through Amazon Mechanical Turk and again used a $2 \times 2$ treatment design. Fifty responses that came from IP addresses outside of the United States were removed from the dataset. As in our first study, respondents saw a male or female candidate with a stereotype-conforming versus stereotype-violating message. Following the message they again rated the candidate on the same traits of warmth, authenticity, and competence as well as rating their feelings about the candidate on a feeling thermometer.

In this study, however, we used real candidates and real campaign ads. For our female candidate, we used Jeanne Shaheen (D-NH) and selected television ads from her 2014 reelection campaign. Her stereotype-conforming ad focused on the issue of childcare and features Shaheen touting her support for childcare tax credits and other forms of government assistance. The ad also shows Shaheen interacting with and hugging happy children. In contrast, in the stereotype-violating condition, respondents watched an ad in which Shaheen discussed her hard opposition to ISIS and the policies that she has supported that crack down on terrorism. While the stereotype-conforming ad contains positive images and smiling children and families, the stereotype-violating ad features military imagery and a harsher tone. Our male candidate was Roy Cooper, and we used ads from his 2016 North Carolina gubernatorial campaign. The stereotypic ad focused on Cooper's role as attorney general in fighting crime, specifically meth dealers. The ad includes an armed S.W.A.T. team breaking down a door and a discussion of Cooper's tough approach to crime. The stereotype-violating ad features Cooper's children and family. His daughters discuss his dedication to family and work as old home videos play. The issues discussed include protecting children and promoting employment, and the imagery portrays loving family moments.

Unlike Study 1, which featured high internal validity due to the use of experimenter-created campaign ads, Study 2 treatments differ not only in the issues presented, but also in tone and candidate appearance, and the scripts were not consistent across candidates. These differences, though decreasing internal validity, are unavoidable in exchange for the higher ecological validity featured in this design. However, the main thrust of each ad fits nicely into a stereotypically masculine or 
feminine framework, and we wanted to see how subjects would respond to actual campaign messages, in addition to responses to news reports. (Note that the candidates we used are not necessarily well-known figures, but to guard against contamination, we asked how familiar respondents were with each candidate. ${ }^{3}$ )

\section{Results}

Despite the reduction in internal validity, the results of our second experiment look remarkably similar to our first. Table 5 shows the descriptive statistics on our trait variables within each condition. Again, however, our main interest is in the interaction between respondent's gender essentialism and the experimental treatment, and we present an analysis parallel to the primary analysis of importance conducted in Study 1, namely an examination of the regression models taking gender essentialism into account. As in Study 1, we see treatment effects and the impact of gender essentialism, but those effects vary depending on the gender of the candidate. Table 6 displays results of our ordered logit models, with the candidate trait ratings as the dependent variables. The interaction term in the model is significant and positive for all three traits for the male candidate, indicating that as respondent essentialism rose and the candidate presented a stereotypically male message, he was rated as warmer, more authentic, and more competent. The interaction term is also significant for the female candidate on the trait of warmth, though not in the expected direction; on that trait, the female candidate actually received higher ratings from high gender-essentialist respondents when the candidate presented a stereotype-violating message. Also, unlike Study 1, we do find a significant respondent gender effect on the traits of competence and authenticity for the female candidate, such that female respondents provided higher ratings on these traits.

Turning to the feeling-thermometer ratings, the interaction between gender essentialism and campaign message is significant for both the male and female candidate, but the interaction term is in an unexpected direction for the female candidate (Table 7). This effect is better understood once we take a derivative of the regression model and look at the conditional effect of messaging given a respondent's gender-essentialist beliefs. Figure 2 shows how the effect of the message varies. For a male candidate, we see expected results: The higher a respondent's gender essentialism, the more positive he or she feels when the candidate runs a stereotypically male message. The lower the respondent's essentialist beliefs, the more negatively they respond to stereotypic messages.

This finding is not true for our female candidate. Those ranking lowest in gender essentialism actually responded most positively to a stereotypically female message, and this effect weakens, rather than strengthening as respondents' essentialism increases. At the highest end of the essentialist spectrum, in fact, the effect of stereotypically female messages is negative, though not statistically distinguishable from zero.

The results from our first two studies are remarkably similar even with the changes in design from Study 1 to Study 2. We consistently see female candidates perform better with stereotypically feminine messages. Even respondents who should be most inclined to reject gender stereotypes provided more positive evaluations of a female candidate who ran a stereotypical message. The male candidate faced a more interesting interaction, with low essentialist respondents preferring a nonstereotypic message and high essentialist respondents preferring the masculine stereotype. Our findings suggest that male candidates face a more complex campaign environment, whereas the strategy that women may best benefit from is fairly straightforward, albeit inherently limited. Our studies of adults are troubling because they suggest that stereotypes will continue to have an impact

${ }^{3}$ Only 26 of our respondents were "extremely familiar" or "very familiar" with the candidates. We have excluded these respondents from all of our analyses. Including these respondents does not substantively alter our results, which is not surprising considering that they make up such a small portion of our data. 
Gender Essentialism and Stereotypic Campaigns

13

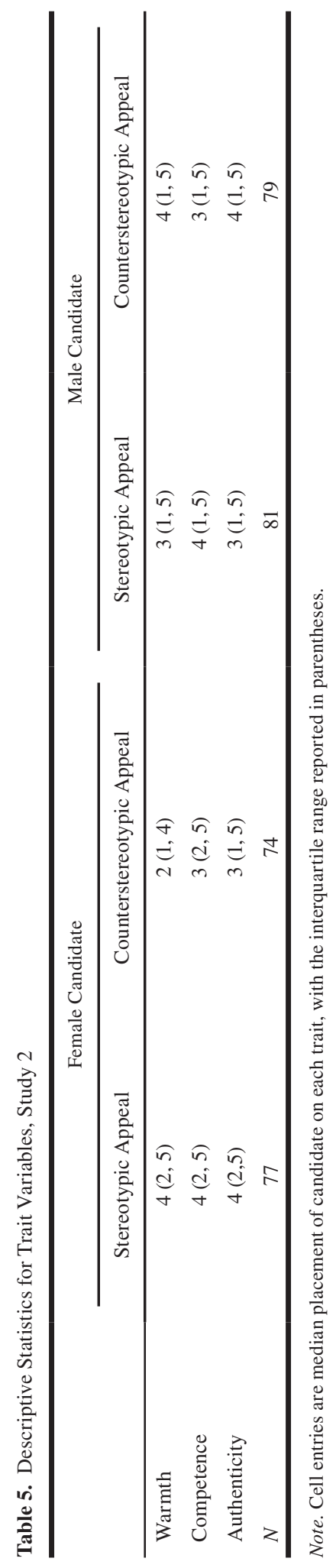




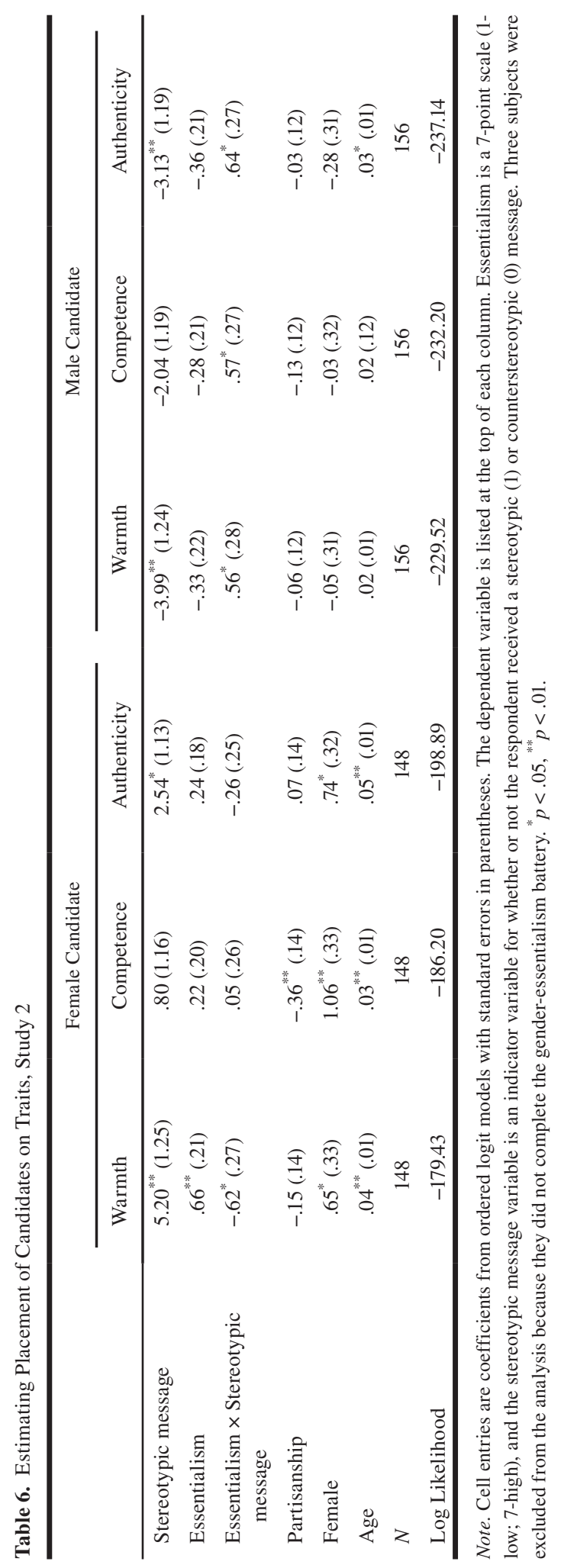


Table 7. Estimating Feeling-Thermometer Ratings, Study 2

\begin{tabular}{lcc}
\hline & Female Candidate & Male Candidate \\
\hline Stereotypic message & $33.55^{* *}(11.62)$ & $-35.81^{*}(13.64)$ \\
Essentialism & $5.49^{* *}(1.95)$ & $-1.01(2.36)$ \\
Essentialism $\times$ Stereotypic message & $-4.74(2.62)$ & $6.46^{*}(3.10)$ \\
Partisanship & $-2.31(1.63)$ & $1.97(1.90)$ \\
Female & $7.03^{* *}(3.21)$ & $.77(3.74)$ \\
Age & $.39^{* *}(.14)$ & $.08(.14)$ \\
Constant & $21.11(10.06)$ & $67.03(11.31)$ \\
$\mathrm{R}^{2}$ & .23 & .10 \\
$N$ & 147 & 156 \\
\hline
\end{tabular}

Note. Cell entries are coefficients from OLS model with standard errors in parentheses. The dependent variable is the respondent's placement of the candidate on a 0-100 feeling thermometer. Essentialism is a 7-point scale (1-low; 7-high), and the stereotypic message variable is an indicator variable for whether or not the respondent received a stereotypic (1) or counterstereotypic (0) message. Four subjects were excluded from the analysis either because they did not complete the gender-essentialism battery, or they did not rate the candidate. ${ }^{*} p<.05,{ }^{* *} p<.01$.

on how female candidates are judged even if attitudes on gender change. The least essentialist adults in our sample still preferred stereotypically feminine messages from female candidates.

\section{Discussion}

Our results thus far show a clear pattern: Female candidates benefit from using gender-stereotypic messaging, regardless of the individual's beliefs about gender essentialism, whereas beliefs about gender essentialism actually modify responses to gender-stereotypic messaging when the candidate is male. Similar to findings from previous research (Herrnson et al., 2003; Meeks \& Domke, 2016), we demonstrate that women are better off running "as women," and the gender essentialism of the audience does not appear to affect how the audience reacts to the campaign message. Male candidates were viewed more favorably by respondents low in gender essentialism when they ran counterstereotypic campaigns. However, they faced a backlash from respondents high in gender essentialism, who viewed the male candidate more favorably when he ran a more stereotypically masculine campaign. Our findings would indicate that female candidates face a harsh constraint when they craft campaign messages, but that male candidates must be more aware of their audience, lest they alienate voters at one end of the gender-essentialism spectrum.

While our research sheds light on some important aspects of gendered campaigning, there are limitations to our findings, and, thus, several questions remain. First, although stereotypes clearly matter for evaluations of candidates, some researchers question whether stereotypes affect actual vote choice. For example, Dolan (2014a, 2014b ) demonstrates that partisanship largely cancels out stereotype effects. Given the current level of extreme political polarization in American politics (Achens \& Bartels, 2016), it is hard to argue against partisanship as a more decisive factor than the influence of a campaign message. However, even if partisanship remains the dominant force in general elections, gender stereotypes could still be a major factor in primary or nonpartisan elections. For instance, Meeks and Domke (2016) examined candidates in a primary campaign and found that women who attempted to run nonstereotypic campaigns performed poorly against women who ran "as women." We did not manipulate partisanship in this experiment, nor did we attempt to elicit any kind of vote choice on our respondents. Political party may have an important effect on how respondents judge candidates, possibly overriding gender stereotypes (Dolan, 2014b), or there might 

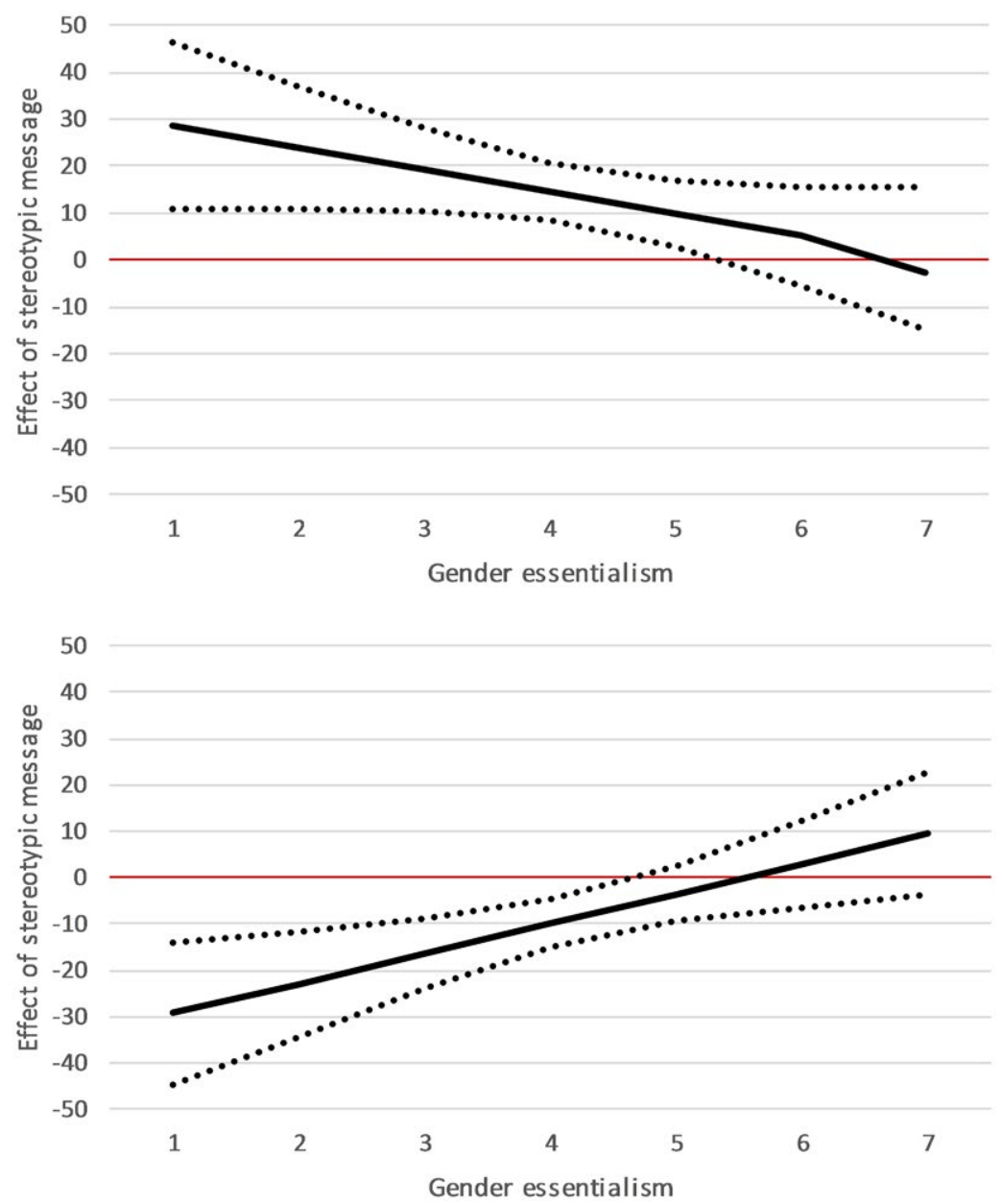

Figure 2. Conditional effect of stereotypic message, Study 2. Each figure shows the effect of a gender-stereotypic campaign message conditional on the respondent's level of gender essentialism. The figure shows the effect as well as the $95 \%$ confidence interval of the estimated effect.

be some three-way interaction between individual predispositions, candidate gender, and gender-stereotypic campaign messages.

Second, it is not clear from the data why gender essentialism would only matter for people's evaluation of stereotypic versus nonstereotypic messages when the candidate is male. One possibility is that low gender essentialists may prefer candidates who focus on feminine issues, regardless of the candidate's gender. If low gender essentialists have different issue priorities, then their responses are not influenced by whether or not a candidate is conforming to or violating gender stereotypes, but by whether or not the candidate is speaking to issues they prioritize. This possibility would also suggest that high gender-essentialist respondents are more likely to notice stereotypic and nonstereotypic behavior in candidates than low gender essentialists. A second possibility is that respondents are more likely to react to stereotypic and counterstereotypic behavior from men. Some research suggests, for example, that many people punish men who engage in feminine behavior more than they would women who engage in masculine behavior (McCreary, 1994; Sirin, McCreary, \& Mahalik, 2004). Perhaps high gender essentialists hold more deeply ingrained beliefs about inherent 
factors contributing to being male versus female and thus may care more about demonstrations of natural or "real" manhood to others. It may be that high essentialists simply expect to see masculine messages from a man and are more likely to punish him for failing to live up to masculine expectations. Again, this explanation would suggest that male candidates actually face a more difficult task when crafting campaign messages.

Because gender essentialism is fairly common (Prentice \& Miller, 2007), candidates may be wise to poll potential voters on gender essentialism. They could also find ways to target high and low gender-essentialism voters with stereotypic and nonstereotypic messages, respectively. There are at least two ways that candidates may consider crafting these messages. First, male candidates could focus on stereotypical or nonstereotypical issues to try to match their constituents. Second, candidates could present images of themselves in stereotypic or nonstereotypic ways. For example, a male candidate interested in attracting essentialist voters could play up his military background or engage in stereotypically masculine activities (sports, hunting, etc.) within an ad to appear more masculine. It is not clear whether candidates should focus on issues, self-presentation, or both in order to appeal to voters. In our own experiments, we did not disentangle these. For example, in Study 2 the counterstereotypic ad for the male candidate featured a man talking about education and also portraying himself as a warm, loving father, and the combination of messages may enhance the overall power of the ad. In practice, these kinds of portrayals often go hand in hand. Ads about education are often much warmer in tone than ads about security or crime. However, in future research we could try separating out these factors to see if counterstereotypic issues or traits might have a larger impact on respondents and examine how candidates can best navigate the trade-off in appealing to high and low gender-essentialist voters.

A final question worthy of future investigation is how respondents react to gendered messaging for political candidates running for offices stereotypically associated with men. Indeed, the intersection of exogenous factors, type of office, and type of campaign appeal is still an area in need of research. As Bos, Schneider, and Utz (2017) point out, the intersection of multiple factors may pose additional challenges (or opportunities) for women seeking office. For example, men and women are judged differently when they run for executive office (Smith, Paul, \& Paul, 2007). We might explore how male candidates would fare if they ran counterstereotypic campaign for a stereotypically male office (e.g., a male presidential candidate who focuses on childcare). It might also be that a female candidate for president would not be capable of running a stereotypically feminine campaign because the office she is seeking is so indelibly seen as a masculine office. Given our findings on the favorability of female candidates who run counterstereotypic campaigns, this is both an intriguing and troubling possibility.

\section{ACKNOWLEDGMENTS}

The authors would like to thank participants from the New Research in Gender and Political Psychology Conference for their valuable feedback, as well as the anonymous reviewers for their comments. Correspondence concerning this article should be addressed to Nathaniel Swigger, The Ohio State University, Department of Political Science, Founders Hall, 1179 University Dr., Newark, OH 43055. Email: swigger.1@osu.edu

\section{REFERENCES}

Achen, C. H., \& Bartels, L. M. (2016). Democracy for realists: Why elections do not produce responsive government. Princeton, NJ: Princeton University Press.

Bastian, B., \& Haslam, N. (2006). Psychological essentialism and stereotype endorsement. Journal of Experimental Social Psychology, 42, 228-235. https://doi.org/10.1016/j.jesp.2005.03.003 
Berinsky, A. J., Huber, G. A., \& Linz, G. S. (2012). Evaluating online labor markets for experimental research: Amazon.com's Mechanical Turk. Political Analysis, 20, 351-368. https://doi.org/10.1093/pan/mpr057

Biernat, M. (1991). Gender stereotypes and the relationship between masculinity and femininity: A developmental analysis. Journal of Personality and Social Psychology, 61, 351-365. https://doi.org/10.1037/0022-3514.61.3.351

Bos, A. L., Schneider, M. C., \& Utz, B. L. (2017). Navigating the political labyrinth: Gender stereotypes in US elections. In C. Travis \& J. White (Eds.), APA handbook of the psychology of women (pp. 367-384). Washington, DC: American Psychological Association.

Brescoll, V., \& LaFrance, M. (2004). The correlates and consequences of newspaper reports of research on sex differences. Psychological Science, 15, 515-520. https://doi.org/10.1111/j.0956-7976.2004.00712.x

Burrell, B. (2008). Likeable? Effective commander in chief? Polling on candidate traits in the "year of the presidential woman." Political Science and Politics, 61, 747-752. https://doi.org/10.107/S1049096508080908

Cassese, E. C., \& Holman, M. R. (2018). Party and gender stereotypes in campaign attacks. Political Behavior, 40(3), 785807. https://doi.org/10.1007/s11109-017-9423-7

Chiu, C., Hong, Y., \& Dweck, C. S. (1997). Lay dispositionism and implicit theories of personality. Journal of Personality and Social Psychology, 73, 19-30.

Diesendruck, G., \& Haber, L. (2009). God's categories: The effect of religiosity on children's teleological and essentialist beliefs about categories. Cognition, 110, 100-114. https://doi.org/10.1016/j.cognition.2008.11.001

Dittmar, K. (2014). Navigating gendered terrain: Stereotypes and strategy in political campaigns. Philadelphia, PA: Temple University Press.

Dolan, K. (2010). The impact of gender stereotyped evaluations on support for women candidates. Political Behavior, 32, 69-88. https://doi.org/10.1007/s11109-009-9090-4

Dolan, K. (2014a). Gender stereotypes, candidate evaluations, and voting for women candidates: What really matters? Political Research Quarterly, 67, 96-107. https://doi.org/10.1177/1065912913487949

Dolan, K. (2014b). When does gender matter? Women candidates and gender stereotypes in American elections. Oxford, United Kingdom: Oxford University Press.

Dolan, J., Deckman, M., \& Swers, M. (2015). Women and politics: Paths to power and political influence. Lanham, MD: Rowman \& Littlefield.

Downs, A. (1957). An economic theory of democracy. New York, NY: Harper.

Dweck, C. (1999). Self theories: Their role in motivation, personality, and development. Philadelphia, PA: Taylor \& Francis.

Eagly, A. H., Wood, W., \& Diekman, A. B. (2000). Social role theory of sex differences and similarities: A current appraisal. Mahwah, NJ: Erlbaum.

Fox, R. L., \& Lawless, J. L. (2005). To run or not to run for office: Explaining nascent political ambition. American Journal of Political Science, 49, 642-659. https://doi.org/10.1111/j.1540-5907.2005.00147.x

Fox, R. L., \& Lawless, J. L. (2010). If only they'd ask: Gender, recruitment, and political ambition. Journal of Politics, 72, 310-326. https://doi.org/10.1017/S0022381609990752

Fridkin, K. L., \& Kenney, P. J. (2009). The role of gender stereotypes in U.S. Senate Campaigns. Politics \& Gender, 5 , 301-324. https://doi.org/10.1017/S1743923X09990158

Gelman, S. A. (2003). The essential child: Origins of essentialism in everyday thought. New York, NY: Oxford University Press.

Gelman, S. A., Collman, P., \& Maccoby, E. E. (1986). Inferring properties from categories versus inferring categories from properties: The case of gender. Child Development, 57, 396-404. https://doi.org/10.2307/1130595

Gil-White, F. J. (2001). Are ethnic groups biological "species" to the human brain? Essentialism in our cognition of some social categories. Current Anthropology, 42, 515-554. https://doi.org/10.1086/321802

Haslam, N. (2000). Psychiatric categories as natural kinds: Essentialist thinking about mental disorders. Social Research, 67, 1031-1058. https://doi.org/10.1111/j.1467-9280.2006.01779.x

Haslam, N., Bastian, B., Bain, P., \& Kashima, Y. (2006). Psychological essentialism, implicit theories, and intergroup relations. Group Processes \& Intergroup Relations, 9, 63-76.

Haslam, N., \& Ernst, D. (2002). Essentialist beliefs about mental disorders. Journal of Social and Clinical Psychology, 21, 628-644. https://doi.org/10.1521/jscp.21.6.628.22793

Haslam, N., Rothschild, L., \& Ernst, D. (2002). Are essentialist beliefs associated with prejudice? British Journal of Social Psychology, 41, 87-100. https://doi.org/10.1348/014466602165072

Herrnson, P. S., Lay, J. C., \& Stokes, A. K. (2003). Women running "as Women": Candidate gender, campaign issues, and voter-targeting strategies. Journal of Politics, 65, 244-255. https://doi.org/10.1111/1468-2508.t01-1-00013

Hirschfeld, L. A. (1996). Race in the making: Cognition, culture, and the child's construction of human kinds. Cambridge, MA: MIT Press. 
Hoffman, C., \& Hurst, N. (1990). Gender stereotypes: Perception or rationalization? Journal of Personality and Social Psychology, 58, 197-208. https://doi.org/10.1037/0022-3514.58.2.197

Holman, M. R., Merolla, J. L., \& Zechmeister, E. J. (2011). Sex, stereotypes, and security: A study of the effects of terrorist threat on assessments of female leadership. Journal of Women, Politics \& Policy, 32(3), 173-192. https://doi.org/10.10 80/1554477X.2011.589283

Huddy, L., \& Terkildsen, N. (1993). Gender stereotypes and the perception of male and female candidates. American Journal of Political Science, 37, 119-147. https://doi.org/10.2307/2111526

Kahn, K. F., \& Kenney, P. J. (1999). The spectacle of U.S. Senate campaigns. Princeton, NJ: Princeton University Press.

Kam, C. D., \& Franzese, R. J. (2006). Modeling and interpreting interactive hypotheses in regression analysis. Ann Arbor: University of Michigan Press.

Koch, J. W. (2002). Gender stereotypes and citizens' impressions of House candidates' ideological orientations. American Journal of Political Science, 46, 453-462. https://doi.org/10.1177/1532673X03255167

Lawless, J. L. (2004). Politics of presence? Congresswomen and symbolic representation. Political Research Quarterly, 57, 81-99. https://doi.org/10.1177/106591290405700107

Levy, S. R., Stroessner, S. J., \& Dweck, C. S. (1998). Stereotype formation and endorsement: The role of implicit theories. Journal of Personality and Social Psychology, 74, 1421-1436. https://doi.org/10.1037/0022-3514.74.6.1421

Mahalingam, R. (2007). Essentialism, power, and the representation of social categories: A folk sociology perspective. Human Development, 50, 300-319. https://doi.org/10.1159/000109832

Martin, C. L., \& Parker, S. (1996). Folk theories about sex and race differences. Personality and Social Psychology Bulletin, 21, 45-57. https://doi.org/10.1177/0146167295211006

McCreary, D. R. (1994). The male role and avoiding femininity. Sex Roles, 31, 517-531. https://doi.org/10.1007/BF01544277

McDermott, M. L. (1997). Voting cues in low-information elections: Candidate gender as a social information variable in contemporary United States elections. American Journal of Political Science, 41, 270-283. https://doi.org/10.2307/2111716

Medin, D. L., \& Ortony, A. (1989). Psychological essentialism. In S. Vosniadou \& A. Ortony (Eds.), Similarity and analogical reasoning (pp. 179-196). New York, NY: Cambridge University Press.

Meeks, L., \& Domke, D. (2016). When politics is a woman's game: Party and gender ownership in woman-versus-woman elections. Communications Research, 43, 895-921. https://doi.org/10.1177/0093650215581369

Meyer, M., \& Gelman, S. A. (2016). Gender essentialism in children and parents: Implications for the development of gender stereotyping and gender-typed preferences. Sex Roles, 75, 409-421. https://doi.org/10.1007/s11199-016-0646-6

Morton, T. A., Postmes, T., Haslam, S. A., \& Hornsey, M. J. (2009). Theorizing gender in the face of social change: Is there anything essential about essentialism? Journal of Personality and Social Psychology, 96, 653-664. https://doi. org/10.1037/a0012966

Offermann, L. R., \& Coats, M. R. (2017). Implicit theories of leadership: Stability and change over two decades. Leadership Quarterly, https://doi.org/10.1016/j.leaqua.2017.12.003

Paolacci, J., \& Chandler, J. (2014). Inside the Turk: Understanding Mechanical Turk as a participant pool. Current Directions in Psychological Science, 23, 184-188. https://doi.org/10.1177/0963721414531598

Paul, D., \& Smith, J. (2008). Subtle sexism? Examining vote preferences when women run against men for the presidency. Journal of Women, Politics, and Policy, 29, 451-476. https://doi.org/10.1080/15544770802092576

Prentice, D. A., \& Miller, D. T. (2006). Essentializing differences between women and men. Psychological Science, 17(2), 129-135. https://doi.org/10.1111/j.1467-9280.2006.01675.x

Prentice, D. A., \& Miller, D. T. (2007). Psychological Essentialism of human categories. Current Directions in Psychological Science, 16(4), 202-206. https://doi.org/10.1111/j.1467-8721.2007.00504.x

Rhodes, M., \& Gelman, S. A. (2009). A developmental examination of the conceptual structure of animal, artifact, and human social categories across two cultural contexts. Cognitive Psychology, 59, 244-274. https://doi.org/10.1016/j. cogpsych.2009.05.001

Rothbart, M., \& Taylor, M. (1992). Category labels and social reality: Do we view social categories as natural kinds? In G. Semin \& K. Fiedler (Eds.), Language, interaction, and social cognition (pp. 11-36). London, United Kingdom: Sage.

Sanbonmatsu, K. (2002). Gender stereotypes and vote choice. American Journal of Political Science, 46, 20-34. https://doi. org/10.2307/3088412

Sanbonmatsu, K., \& Dolan, K. (2009). Do gender stereotypes transcend party? Political Research Quarterly, 62, $485-494$. https://doi.org/10.1177/1065912908322416

Schein, V. E., Mueller, R., Lituchy, T., \& Liu, J. (1996). Think manager-think male: A global phenomenon? Journal of OrganizationalBehavior, 17,33-41.https://doi.org/10.1002/(SICI)1099-1379(199601)17:1<33:AID-JOB778>3.0.C);2-F

Schneider, M. C. (2014). The effects of gender-bending on candidate evaluations. Journal of Women, Politics \& Policy, 35, 55-77. https://doi.org/10.1080/1554477X.2014.863697 
Schneider, M. C., \& Bos, A. L. (2014). Measuring stereotypes of female politicians. Political Psychology, 35, $245-266$. https://doi.org/10.1111/pops. 12040

Simon, A. F. (2002). The winning message: Candidate behavior, campaign discourse, and democracy. Cambridge, United Kingdom: Cambridge University Press.

Sirin, S. R., McCreary, D. R., \& Mahalik, J. R. (2004). Differential reactions to men and women's gender role transgressions: Perceptions of social status, sexual orientation and value dissimilarity. Journal of Men's Studies, 12, 119-132. https:// doi.org/10.3149/jms.1202.119

Smiler, A. P., \& Gelman, S. A. (2008). Determinants of gender essentialism in college students. Sex Roles, 58, 864-874. https://doi.org/10.1007/s11199-008-9402-X

Smith, J. L., Paul, D., \& Paul, R. (2007). No place for a woman: Evidence for gender bias in evaluations of presidential candidates. Basic and Applied Social Psychology, 29, 225-233. https://doi.org/10.1080/01973530701503069

Streb, M. J., Burrell, B., Frederick, B., \& Genovese, M. A. (2008). Social desirability effects and support for a female American president. Public Opinion Quarterly, 72, 76-89. https://doi.org/10.1093/poq/nfm035

Taylor, M. G., Rhodes, M., \& Gelman, S. A. (2009). Boys will be boys; Cows will be cows: Children's essentialist reasoning about gender categories and animal species. Child Development, 80, 461-481. https://doi. org/10.1111/j.1467-8624.2009.01272.x

Yzerbyt, V., Corneille, O., \& Estrada, C. (2001). The interplay of subjective essentialism and entitativity in the formation of stereotypes. Personality and Social Psychology Review, 5, 141-155. https://doi.org/10.1207/S15327957PSPR0502_5

Yzerbyt, V., Rocher, S., \& Schadron, G. (1997). Stereotypes as explanations: A subjective essentialistic view of group perception. Malden, MA: Blackwell.

Yzerbyt, V. Y., Rogier, A., \& Fiske, S. T. (1998). Group entitativity and social attribution: On translating situational constraints into stereotypes. Personality and Social Psychology Bulletin, 24, 1089-1103. https://doi.org/10.1177/014616729824100

\section{Supporting Information}

Additional supporting information may be found in the online version of this article at the publisher's website:

Appendix S1. Fictional Newspaper Articles for Study 1 and Candidate Ad Links for Study 2 Appendix S2. Text of Adult Essentialism Measure (Study 1 and Study 2) 